Vol. 9 (2000): 79-87.

\title{
Bast fibre content, fibre yield and fibre quality of different linseed genotypes
}

\author{
Hannele S. Sankari \\ Agricultural Research Centre of Finland, Plant Production Research, FIN-31600 Jokioinen, \\ Finland,e-mail:hannele.sankari@mtt.fi
}

\begin{abstract}
Linseed (Linum usitatissimum L.) grown for seed does not compete well with flax in fibre yield, but as a by-product of seed production its stems could be used in non-woven products. With the aim of discovering suitable linseed genotypes to be cultivated for dual-purpose use in Finland, Finnish linseed $\mathrm{cv}$. Helmi was compared with ten other linseed genotypes and one flax cultivar for stem yield, bast fibre content in stem, stem length and diameter and bast fibre yield. In addition, breaking tenacity and elongation at break of the fibres were determined. The experiments were carried out in 1996-1997 at the Agricultural Research Centre (MTT) in Jokioinen, Finland (latitude $60^{\circ} 49^{\prime} \mathrm{N}$ ). Bast fibre content in stem averaged $16.9 \%$ and breeding line Bor 18 had significantly higher bast fibre content than cv. Helmi. Bast fibre yield averaged $301 \mathrm{~kg}$ dry matter ha ${ }^{-1}$. Compared with $\mathrm{cv}$. Helmi, breeding lines Bor 15 and Bor 18 and cvs. Flanders and Gold Merchant produced significantly higher fibre yield. The median for breaking tenacity varied among the genotypes between 41 and $67 \mathrm{cN} /$ tex and the median for elongation at break between 3.5 and 6.8\%. Finnish breeding line Bor 18 is recommended for cultivation as dual-purpose linseed in Finland.
\end{abstract}

Key words: breeding lines, cultivars, dual-purpose use, fibre elasticity, fibre strength, Linum usitatissimum L., plant fibres, stems

\section{Introduction}

Linum usitatissimum L. is generally cultivated either for fibre production using flax cultivars or for seed production using linseed cultivars. Recently the dual-purpose use of both seed and stem has been studied, for example by Kaul et al. (1994) and Foster et al. (1997). The fact is, however, as reported by Easson and Molloy (1996), that fibre yield of flax is very much higher than that of linseed (1366-2267 $\mathrm{kg} \mathrm{ha}^{-1}$ vs. $451-837 \mathrm{~kg} \mathrm{ha}^{-1}$ ). Foster et al. (1997) concluded accordingly, that neither linseed nor flax is likely to exhibit both high seed yield and high fibre yield.

However, if linseed stems were used as well as seeds, the utility and processing value of the crop would increase, and so the farmer's income (Reijonen 1998). The optimum stage for fibre harvest of linseed is past at seed maturity and 


\section{AGRICULTURAL AND FOOD SCIENCE IN FINLAND}

\section{Sankari, H.S. Bast fibre content, fibre yield and fibre quality of different linseed}

the fibre is not suitable for traditional textile use, but perhaps it could be processed and used in the new non-woven products. One of the advantages of linseed is that retting of stems is not required at all, as stems are ready for breaking immediately after drying (Reijonen 1998).

At the moment, only a limited amount of information is available concerning the physical properties and processing of linseed fibres (Reijonen 1998). In fact, until now, besides the preliminary study of Mäkinen (1998), nothing has been published about the bast fibre content in stem or the fibre yield of either Finnish linseed genotypes or the non-domestic cultivars grown in Finnish conditions. To provide new information on the topic, this paper reports on stem yield, bast fibre content in stem, stem length and diameter, bast fibre yield, breaking tenacity of the fibres and elongation at break of the fibres.

\section{Material and methods}

\section{Experimental procedure}

Linseed bast fibres were studied in field experiments carried out in 1996-1997 at the Agricultural Research Centre (MTT) in Jokioinen, Finland (latitude $60^{\circ} 49^{\prime} \mathrm{N}$ ). The experiments were laid out in a randomized complete block design with four blocks. Cvs. Helmi (FIN), Gold Merchant (UK) and Norlin (CAN) and breeding lines Bor 13 and Bor 18 (FIN) were included in the experiments in both years, whereas cvs. Flanders (CAN), Laser and Linus (UK), linseed breeding lines Bor 02, Bor 15 and Bor 20 (FIN) and flax cv. Martta (FIN) were included in only one or the other growing season. In 1997, the fourth block of the experiment was discarded due to poor establishment. Weather data, agronomic details and determination of stem yields are described by Sankari (2000).

Just before seed threshing, plant samples were pulled to determine the plant stand density (Sankari 2000). From among these plants, 25 plants in 1996 and ten in 1997 were randomly chosen for measurements of stem length (from root collar to the top of the plant) and stem diameter (in the middle of the stem). Stem measurements for cv. Gold Merchant are lacking in 1997. Five of the measured plants in 1996 and all ten plants in 1997 were used to determine the bast fibre content in stems: the number of plants was doubled in 1997 to obtain more reliable results, as has been discussed in Bredemann (1942).

The plants for determination of bast fibre content were first cut at root collar and capsules were removed. Stem samples were weighed before retting, and two more crushed stems were used to determine the moisture content in stem by oven drying at $80^{\circ} \mathrm{C}$ for $17 \mathrm{~h}$. Stems were retted using liquid enzyme SP 249 (Novo Nordisk $\mathrm{A} / \mathrm{S}$, Denmark) in a $0.3 \%$ enzyme solution (in water) at $30^{\circ} \mathrm{C}$ for two days, until the fibres easily were separated by hand. The fibres were next rinsed with tap water. Pure fibres ("Reinfaser", Bredemann 1922), were obtained by boiling the fibres for 10 minutes in a $2 \% \mathrm{NaOH}$ solution and then rinsing them with an intense jet of water to remove non-fibrous material such as pieces of epidermis and parenchyma from bast fibres. The fibres were dried naturally at room temperature for several weeks, after which the dry weight of the fibres was determined by oven drying at $60^{\circ} \mathrm{C}$ for $17 \mathrm{~h}$. The bast fibre content in stem (\%) was calculated by dividing the fibre dry weight by the dry weight of the stems. Bast fibre yield (kg dry matter ha ${ }^{-1}$ ) was calculated by multiplying stem yield ( $\mathrm{kg}$ dry matter $\mathrm{ha}^{-1}$ ) by fibre content $(\%)$.

For analysis of fibre quality, twelve air-dry stems of each genotype from one of the replicates in 1996 were randomly selected from among the plants chosen for plant density determinations. Bast fibre strings about $20 \mathrm{~cm}$ in length and $1-2 \mathrm{~mm}$ in width were separated by hand from the middle part of stems. Fibre quality was determined at the Tampere University of Technology, Institute of Fiber, Textile and Clothing Science. First the fibre strings were 


\section{AGRICULTURAL AND FOOD SCIENCE IN FINLAND}

\section{Vol. 9 (2000): 79-87.}

made shorter and finer by hand and the fibre fineness (dtex), i.e. length-related mass, was determined with a vibroscope (Lenzing AG, Austria) to allow calculation of breaking tenacity of the fibres. Breaking tenacity of the fibres (cN/tex), i.e. maximum breaking force applied to a test specimen carried to rupture, divided by the linear density, and elongation at break of the fibres (\%), i.e. the elongation of a test specimen produced by the breaking force, were measured according to standard SFS-EN ISO 5079 (ISO $5079,1995(\mathrm{E}))$ in the conditioned state using an Alwetron TCT device (Ab Lorenzen \& Wettre, Sweden). The initial gauge length was $20 \mathrm{~mm}$ and the constant rate of extension (CRE) that was applied was $20 \mathrm{~mm} \mathrm{~min}^{-1}$.

\section{Statistical methods}

The data for the two years were analysed together with the MIXED procedure of SAS Statistical Software (SAS Institute Inc. 1992). Before the analysis, accordances of the data with the assumptions of equality of group variances were checked with Box-Cox diagnostic plots (Neter et al. 1996), and the normality assumption of errors was assessed by stem and leaf display and by normal probability plot. Stem yield, bast fibre content in stem, stem length and diameter and bast fibre yield were analysed by applying mixed models. The genotype was analysed as a fixed effect, whereas year and replicate nested in years were analysed as random effects. Because the Finnish cv. Helmi dominates the present cultivation area for linseed in Finland, the ten other linseed genotypes and one flax cultivar were compared with cv. Helmi. For this comparison, the ESTIMATE statement of the MIXED procedure was used to produce ttype contrasts and t-type $95 \%$ confidence intervals.

The data for breaking tenacity and elongation at break of the fibres were obtained from just one replicate in 1996. For comparison of the genotypes, therefore, the UNIVARIATE procedure (SAS Institute Inc. 1991) was applied to produce the parameters median (middle value to be measured), 25 th percentile (first quartile, i.e. value is greater than 25 per cent of the values to be measured) and 75th percentile (third quartile).

\section{Results and discussion}

The average stem yield was $2018 \mathrm{~kg}$ dry matter ha $^{-1}$ (standard deviation, SD, 428) in 1996 and $1640 \mathrm{~kg}$ dry matter ha ${ }^{-1}$ (SD 737) in 1997. The overall mean for stem yield was $1820 \mathrm{~kg}$ dry matter $\mathrm{ha}^{-1}$ (standard error of the mean, S.E.M., 66). The difference in stem yield among the genotypes was statistically significant $\left(\mathrm{F}_{11,42}\right.$ $=4.93, \mathrm{P}<0.001)$. (Hereafter, differences are always statistically significant when the term significant is used). Five genotypes, inclusive of Finnish breeding lines Bor 15 and Bor 18 and non-domestic cvs. Flanders, Gold Merchant and Norlin, produced significantly higher stem yield than cv. Helmi (Table 1). Productivity of linseed stem yield in the years 1995-1997 is discussed in more detail by Sankari (2000).

Besides stem yield, bast fibre content is needed in the determination of bast fibre yield. Bast fibre content averaged 16.2\% (SD 1.4) in 1996 and $17.4 \%$ (SD 2.3) in 1997, and the overall mean for bast fibre content in stem was $16.9 \%$ (S.E.M. 0.7). The difference in bast fibre content among the genotypes was significant $\left(\mathrm{F}_{11,42}=15.45, \mathrm{P}<0.001\right)$. However, only breeding line Bor 18 exhibited significantly higher fibre content in stem than cv. Helmi (Table 1). Examination of the $95 \%$ confidence interval revealed that the true difference in fibre content between these two genotypes varied from an insignificant difference of $0.1 \%$ up to $1.9 \%$. It is notable that the non-domestic cultivars Flanders, Laser and Linus did not differ significantly from cv. Helmi, and cv. Norlin had significantly lower bast fibre content in stem (Table 1).

Mäkinen (1998) reports average values of bast fibre content of a little under $15 \%$ in unret- 


\section{Sankari, H.S. Bast fibre content, fibre yield and fibre quality of different linseed}

Table 1. The effect of Linum usitatissimum genotype on stem yield ( $\mathrm{kg}$ dry matter ha ${ }^{-1}$ ), bast fibre content in stem (\%) and bast fibre yield ( $\mathrm{kg}$ dry matter ha ${ }^{-1}$ ). Means (lsmeans), corresponding 95\% confidence intervals for the differences in stem yield, bast fibre content in stem and bast fibre yield and statistical significance of the difference between cv. Helmi and other Linum usitatissimum genotypes (P-values).

\begin{tabular}{|c|c|c|c|c|c|c|c|c|c|}
\hline \multirow[b]{2}{*}{ Genotype } & \multicolumn{3}{|c|}{ Stem yield } & \multicolumn{3}{|c|}{ Bast fibre content } & \multicolumn{3}{|c|}{ Bast fibre yield } \\
\hline & $\begin{array}{l}\text { Difference } \\
\mathrm{kg} \mathrm{ha}^{-1}\end{array}$ & $\begin{array}{l}\text { Confidence } \\
\text { interval }\end{array}$ & $\mathrm{P}$-value & $\begin{array}{l}\text { Difference } \\
\%\end{array}$ & $\begin{array}{l}\text { Confidence } \\
\text { interval }\end{array}$ & $\mathrm{P}$-value & $\begin{array}{l}\text { Difference } \\
\mathrm{kg} \mathrm{ha}^{-1}\end{array}$ & $\begin{array}{l}\text { Confidence } \\
\text { interval }\end{array}$ & $\mathrm{P}$-value \\
\hline Helmi & \multicolumn{3}{|c|}{1533 (mean) } & \multicolumn{3}{|l|}{17.5 (mean) } & \multicolumn{3}{|l|}{266 (mean) } \\
\hline Bor 02 & -512 & $(-1138,114)$ & 0.11 & 0.6 & $(-0.6,1.8)$ & 0.33 & -76 & $(-176,24)$ & 0.13 \\
\hline Bor 13 & -175 & $(-659,308)$ & 0.47 & 0.4 & $(-0.5,1.3)$ & 0.42 & -27 & $(-104,50)$ & 0.48 \\
\hline Bor 15 & 606 & $(37,1174)$ & 0.037 & 0.4 & $(-0.7,1.4)$ & 0.51 & 102 & $(11,193)$ & 0.029 \\
\hline Bor 18 & 518 & $(34,1001)$ & 0.037 & 1.0 & $(0.1,1.9)$ & 0.027 & 109 & $(32,186)$ & 0.07 \\
\hline Bor 20 & 363 & $(-205,931)$ & 0.20 & -0.7 & $(-1.8,0.4)$ & 0.21 & 40 & $(-51,131)$ & 0.39 \\
\hline Flanders & 733 & $(165,1301)$ & 0.013 & -0.5 & $(-1.6,0.6)$ & 0.37 & 105 & $(14,196)$ & 0.025 \\
\hline Gold Merchant & 1048 & $(565,1532)$ & $<0.001$ & -3.4 & $(-4.3,-2.5)$ & $<0.001$ & 98 & $(21,175)$ & 0.014 \\
\hline Laser & 261 & $(-365,888)$ & 0.40 & -1.1 & $(-2.3,0.2)$ & 0.09 & 38 & $(-62,139)$ & 0.44 \\
\hline Linus & -325 & $(-952,301)$ & 0.30 & -1.2 & $(-2.4,0.0)$ & 0.051 & -60 & $(-161,40)$ & 0.23 \\
\hline Martta $^{\#}$ & 434 & $(-134,1002)$ & 0.13 & -0.1 & $(-1.1,1.0)$ & 0.91 & 63 & $(-28,153)$ & 0.17 \\
\hline Norlin & 499 & $(16,983)$ & 0.043 & -2.6 & $(-3.5,-1.7)$ & $<0.001$ & 31 & $(-46,109)$ & 0.42 \\
\hline
\end{tabular}

\# flax

ted stems of cvs. Helmi and Norlin, and over $20 \%$ for flax cv. Martta. The stubble height at which the stems were cut for this determination was not announced. In my study, where fibre content was determined for stems cut at root collar, bast fibre content of flax cv. Martta did not differ significantly from that of cv. Helmi, while bast fibre content of cv. Norlin was significantly lower (Table 1).

Stem length and stem diameter were determined in order to examine the relationship between these plant characters and fibre content in stem. Kaul et al. (1994) have reported a positive correlation between plant height and fibre content in stem and fibre yield for Linum usitatissimum genotypes. Similarly, Turner (1987) concluded that thin flax stands with fine and tall stems produce high fibre yields with good fibre quality. In the present study, stem length averaged $65.9 \mathrm{~cm}$ (SD 6.2) in 1996 and only $51.6 \mathrm{~cm}$ (SD 4.6) in 1997. The overall mean for stem length was $58.9 \mathrm{~cm}$ (S.E.M. 5.5). The difference in stem length among the genotypes was statistically significant $\left(\mathrm{F}_{11,39}=25.04, \mathrm{P}<0.001\right)$ : linseed genotypes Bor 15, Bor 18 and Norlin and flax cv. Martta had significantly higher stem lengths in comparison with cv. Helmi (Table 2).

Stem diameter averaged $1.9 \mathrm{~mm}(\mathrm{SD} 0.2)$ in 1996 but was only $1.5 \mathrm{~mm}$ (SD 0.1) in 1997. The overall mean was $1.7 \mathrm{~mm}$ (S.E.M. 0.2). The difference in stem diameter among the genotypes was significant $\left(\mathrm{F}_{11,39}=11.06, \mathrm{P}<0.001\right)$, and cvs. Flanders, Gold Merchant, Norlin and Martta produced significantly thicker stems than $\mathrm{cv}$. Helmi (Table 2).

In regard to the linseed genotypes Bor 13, Bor 18, Helmi and Norlin, all of which were measured for stem length and stem diameter in both experimental years, scatter plots of the yearly average fibre contents against yearly average stem lengths and stem diameters showed the fibre content in stems of all these genotypes to increase as the stem length and stem diameter decreased (Fig. 1). Although all four cultivars exhibited the same behaviour, data from just two experimental years, i.e. two scatter plots per genotype, are insufficient for hard conclusions. The combination of long stem length and thick stem diameter in 1996 did, however, produce clearly higher fibre content in stem than did the 
Vol. 9 (2000): 79-87.

Table 2. The effect of Linum usitatissimum genotype on stem length (cm) and stem diameter ( $\mathrm{mm}$ ). Means (lsmeans), corresponding 95\% confidence intervals for the differences in stem length and stem diameter and statistical significance of the difference between cv. Helmi and other Linum usitatissimum genotypes (P-values).

\begin{tabular}{|c|c|c|c|c|c|c|}
\hline \multirow[b]{2}{*}{ Genotype } & \multicolumn{3}{|c|}{ Stem length } & \multicolumn{3}{|c|}{ Stem diameter } \\
\hline & $\begin{array}{l}\text { Difference } \\
\mathrm{cm}\end{array}$ & $\begin{array}{l}\text { Confidence } \\
\text { interval }\end{array}$ & P-value & $\begin{array}{l}\text { Difference } \\
\mathrm{mm}\end{array}$ & $\begin{array}{l}\text { Confidence } \\
\text { interval }\end{array}$ & P-value \\
\hline Helmi & 58.2 (mean) & & $1.6($ mean $)$ & & & \\
\hline Bor 02 & -0.2 & $(-3.5,3.2)$ & 0.93 & 0.0 & $(-0.1,0.2)$ & 0.54 \\
\hline Bor 13 & -3.5 & $(-6.0,-1.0)$ & 0.007 & -0.1 & $(-0.2,0.0)$ & 0.11 \\
\hline Bor 15 & 4.3 & $(1.3,7.3)$ & 0.007 & 0.0 & $(-0.2,0.1)$ & 0.61 \\
\hline Bor 18 & 3.6 & $(1.1,6.1)$ & 0.006 & 0.0 & $(-0.1,0.1)$ & 0.69 \\
\hline Bor 20 & -2.3 & $(-5.3,0.8)$ & 0.14 & -0.1 & $(-0.3,0.0)$ & 0.08 \\
\hline Flanders & -2.7 & $(-5.8,0.3)$ & 0.07 & 0.2 & $(0.0,0.3)$ & 0.013 \\
\hline Gold Merchant & 0.8 & $(-2.2,3.8)$ & 0.59 & 0.3 & $(0.2,0.5)$ & $<0.001$ \\
\hline Laser & -4.8 & $(-8.2,-1.4)$ & 0.007 & 0.1 & $(0.0,0.3)$ & 0.16 \\
\hline Linus & -6.4 & $(-9.8,-3.0)$ & $<0.001$ & 0.0 & $(-0.1,0.2)$ & 0.82 \\
\hline Martta $^{\#}$ & 16.6 & $(13.6,19.7)$ & $<0.001$ & 0.2 & $(0.0,0.3)$ & 0.015 \\
\hline Norlin & 3.4 & $(0.9,5.9)$ & 0.009 & 0.3 & $(0.3,0.5)$ & $<0.001$ \\
\hline
\end{tabular}

combination of short stem and thin stem diameter in 1997.

Mäkinen (1998) determined the fibre content in stems in the same plants that were cut at harvest at an unknown stubble height to determine stem yield, so that the calculated fibre yield per hectare would be a realistic approximation of the true value. In my study, the fibre content was determined in the whole stem, while the stem yield was determined in stems harvested at $5 \mathrm{~cm}$ stubble height. Since the fibre yields for the different genotypes were determined from fibre content and stem yield in a similar way, the comparisons between $\mathrm{cv}$. Helmi and the other genotypes are meaningful. However, the calculated fibre yields per hectare are probably somewhat lower than the true values, which would been obtained if stems for fibre content analysis had been cut at $5 \mathrm{~cm}$ stubble height. This conclusion assumes that the fibre content along linseed stem varies in a similar way to that of fibre hemp (Cannabis sativa L.). Werf et al. (1994) devided hemp stems into ten sections of equal length and found that the bast fibre content at the base of the stem was lower than the average for the whole stem.
Calculated bast fibre yield averaged $324 \mathrm{~kg}$ dry matter ha ${ }^{-1}$ (SD 63) in 1996 and $280 \mathrm{~kg}$ dry matter ha ${ }^{-1}$ (SD 113) in 1997. The overall mean was $301 \mathrm{~kg}$ dry matter ha ${ }^{-1}$ (S.E.M. 11), which was clearly lower than the fibre yield for linseed reported by Easson and Molloy (1996). According to Kämmerling (1990), harvest method has an effect on flax fibre yield; the loss in fibre yield averaged 19\% when the flax stubble was left in the field instead of the whole plant being pulled.

In the present study, the difference in bast fibre yields among the genotypes was significant $\left(\mathrm{F}_{11,42}=3.52, \mathrm{P}=0.002\right)$. Relative to cv. Helmi, breeding lines Bor 15 and Bor 18 and nondomestic cvs. Flanders and Gold Merchant produced significantly higher fibre yields (Table 1). Examination of the lower limit of the $95 \%$ confidence interval of these four genotypes suggested, that the true differences between them and cv. Helmi may be insignificant in practice (Table 1). The upper limit of the 95\% confidence interval, in turn, showed true fibre yields almost $200 \mathrm{~kg}$ higher for these genotypes than for cv. Helmi. Such yield increases would be of practical importance. The yields also ap- 
Sankari, H.S. Bast fibre content, fibre yield and fibre quality of different linseed
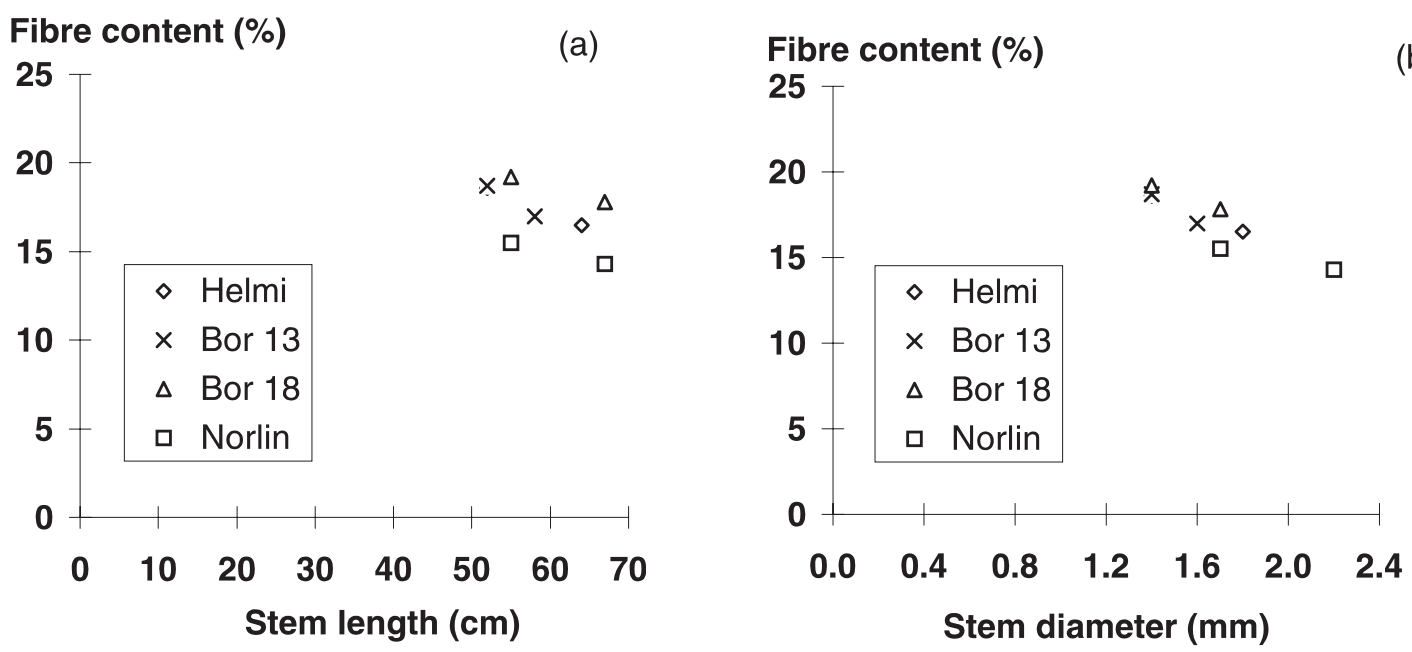

Fig. 1. Relationship between the yearly average fibre content in stem and the yearly average stem length (a) and between the yearly average fibre content in stem and the yearly average stem diameter (b) of the linseed genotypes Helmi, Bor 13, Bor 18 and Norlin in 1996-1997.

proached the linseed fibre yield range of 451 and $837 \mathrm{~kg} \mathrm{ha}^{-1}$ reported by Easson and Molloy (1996). Causion is needed in the comparison, however, as materials and methods were not reported in the earlier study.

Use of linseed fibre is being considered for several products, but as yet our knowledge of the physical properties of linseed fibre is inadequate. Compared with other natural fibres and most man-made fibres, the fibres of Linum usitatissimum are relatively inelastic and constant in shape. Depending on the end use, these characteristics may be either advantageous or disadvantageous (Mäkinen 1998). In the present study, breaking tenacity (cN/tex) and elongation at break $(\%)$ of the fibres were analysed as fibre quality indicators. Measurement of fibre fineness (dtex) was required for the calculation of breaking tenacity. According to Herzog (1989), the fineness of flax bast fibre bundles varies from 10 to $200 \mathrm{dtex}$, whereas that of a single fibre varies from 1 to $8 \mathrm{dtex}$. The fineness values obtained in the present study varied between 13.6 and $66.8 \mathrm{dtex}$, and it was concluded that the breaking tenacity of the fibre bundles, not that of single fibres, had been measured at Tampere. Fineness varies with the shape and length of single fibre cells, the number of single fibre cells in the fibre bundle measured and the processing method (Mäkinen 1998). The wide variation in the values of fibre fineness in this study can be attributed to the hand treatment of the fibre string samples.

The parameter median for breaking tenacity of the fibres varied from 41 to $67 \mathrm{cN} / \mathrm{tex}$, depending on the genotype (Fig. 2a). The median for $\mathrm{cv}$. Helmi was one of the lowest. The line segments in Figure 2 represent the interquartile range inside of which $50 \%$ of the observations of each genotype are included. Judging from the lengths of the segments, the fibre quality was highly heterogeneous, especially for breeding lines Bor 13 and Bor 15. Linseed cv. Norlin and flax cv. Martta showed the best fibre uniformity, but even then the range of the fibre strength was wide, about $30 \mathrm{cN} /$ tex. According to Herzog (1989), the strength of a good quality flax bast fibre, expressed as $\mathrm{cN} /$ tex, should be at minimum 60. Kromer et al. (1995) report that the strength of unretted flax fibre bundles is double 
Vol. 9 (2000): 79-87
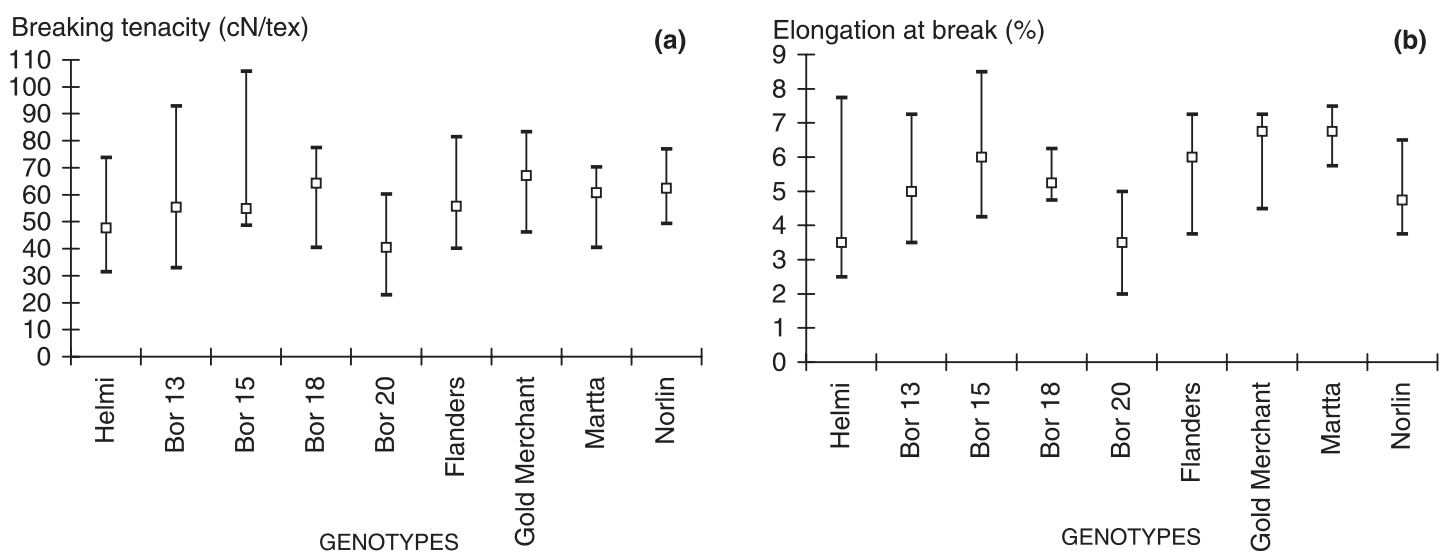

Fig. 2. Median ( $\square)$, 25th percentile $(\perp)$ and 75 th percentile $(\top)$ for breaking tenacity (cN/tex) (a) and elongation at break (\%) (b) of the fibres of Linum usitatissimum genotypes in 1996.

that of retted bast fibre bundles. However, the factor responsible for fibre strength is not entirely clear. Thus, in the study of Meijer et al. (1995) the strength of unretted flax fibres varied between 30 and $40 \mathrm{cN} /$ tex, while that of water retted fibres was higher and that of field retted fibres lower. Furthermore, Mäkinen (1998) reported highest strength of linseed fibres for unretted and field retted stems and lowest values for fibres derived from water or enzyme retting.

According to Foster et al. (1997), earlier matured fibres become coarse and lignified by the time the seeds of flax or linseed mature and the fibres are unsuitable for linen making. It bears notice that linseed stems are not always unretted at seed threshing. Sometimes retting of fibre bundles is obvious already in stems of the standing crop. This was observed in linseed experiments carried out in 1998 at Jokioinen, when, as a result of a wet and long growing time, the fibre bundles in the stems became grey and loosened from the stems before seed maturity. According to Meijer et al. (1995) and Easson and Molloy (1996), over-retting of fibres causes weakening of the fibres. If flax remains unretted, however, as probably most often is the case for linseed stems at seed harvest, the flax fibres that are obtained are coarse owing to the inadequate sepa- ration of fibres from the surrounding parenchyma and from the bundles (Meijer et al. 1995). It can be concluded that fibres of linseed stems at seed harvest may be unretted or partly retted, according to the weather and time of harvest, and the fibre quality will vary accordingly.

Fibre quality was also determined by measuring the elongation at break. Fibre elongation affects the elasticity properties and shape constancy of a product (Mäkinen 1998). The median for elongation at break of the fibres varied from 3.5 to $6.8 \%$ depending on genotype (Fig. $2 \mathrm{~b})$. A comparison of the median values shows flax cv. Martta and linseed cv. Gold Merchant to have the greatest elongation of fibres. Mäkinen (1998) reports average values between 3 and 4\% for unretted fibres of cvs. Helmi, Norlin and Martta. In my study, the lengths of the line segments in Fig. 2b show the fibres of cv. Martta and breeding line Bor 18 to be the most uniform ones, while those of cv. Helmi and breeding line Bor 15 show an especially wide variation in elongation at break of the fibres.

In view of the low bast fibre yield per hectare in comparison with other fibre crops, Mäkinen (1998) concluded that linseed fibre cannot be competitive unless it is cultivated in such large areas that the fibre demand is met. At the mo- 


\section{AGRICULTURAL AND FOOD SCIENCE IN FINLAND}

\section{Sankari, H.S. Bast fibre content, fibre yield and fibre quality of different linseed}

ment there is no demand for linseed fibre in Finland, but total bast fibre yield of $585200 \mathrm{~kg}$ dry matter ha ${ }^{-1}$ would be obtained yearly if 2200 hectares were planted to linseed, as in 1997, and the average fibre yield was the value obtained for cv. Helmi in this study. The area planted to linseed varies from year to year, however, and owing to the clearly higher seed than fibre productivity of linseed, the main goal in cultivation inevitably will be the seed production. If the current seed production already corresponds to demand, it will be difficult to increase the cultivated area of linseed for the purpose of producing more fibre.

Early maturity and both high seed and high stem yield of linseed genotypes were of interest in an earlier study (Sankari 2000), where linseed breeding lines Bor 15 and Bor 18 were recommended for cultivation for dual-purpose use instead of the commonly cultivated cv. Helmi. The additional results of the present study concerning the linseed bast fibres show that the Finnish breeding lines Bor 15 and Bor 18 and nondomestic cvs. Flanders and Gold Merchant all produce significantly higher fibre yield than $\mathrm{cv}$.
Helmi. However, linseed genotypes Bor 15 and Flanders were included in the fibre analysis in just one year and the data are thus too few to be taken as the basis for recommendation of suitability for dual-purpose use. The fibre quality was more heterogenous for these two genotypes than for breeding line Bor 18. Late maturing non-domestic linseed cultivars are always a risk for the Finnish farmer as long as the price for harvested seed is based on quality indicators, such as the chlorophyll content in the seed oil. Cvs. Flanders and Gold Merchant cannot be recommended for cultivation in Finnish conditions, therefore. The Finnish linseed breeding line Bor 18 (Boreal Plant Breeding, Finland), on the other hand, is unhesitatingly recommended for a new commercial cultivar to be cultivated as a dual-purpose linseed in Finland.

Acknowledgements. I wish to thank Kauko Kyläsorri for taking care of the field experiments and assistance in data entry, and Leila Salo for assisting with the fibre content analysis. The study was financed by the Ministry of Agriculture and Forestry and the Agricultural Research Centre of Finland.

\section{References}

Bredemann, G. 1922. Die Bestimmung des Fasergehaltes in Bastfaserpflanzen bei züchterischen Untersuchungen. Faserforschung 2: 239-258.

- 1942. Die Bestimmung des Fasergehaltes bei Massenuntersuchungen von Hanf, Flachs, Fasernesseln und anderen Bastfaserpflanzen. Faserforschung 16: 14-39.

Easson, D.L. \& Molloy, R. 1996. Retting - a key process in the production of high value fibre from flax. Outlook on Agriculture 4: 235-242.

Foster, R., Pooni, H.S. \& Mackay, I.J. 1997. Quantitative evaluation of Linum usitatissimum varieties for dual-purpose traits. Journal of Agricultural Science, Cambridge 129: 179-185.

Herzog, W. 1989. Objektive Qualitätsprüfung von Flachs. Melliand Textilbericht 1: 7-11.

ISO 5079. 1995(E). Textile fibres - Determination of breaking force and elongation at break of individual fibres. 2nd ed. International Organisation for Standardization, Switzerland. 6 p.

Kämmerling, B. 1990. Die Bedeutung von Anbau- und
Ernteverfahren sowie der Sorte für die Nutzung eines zur Kurzfasergewinnung geeigneten Leins. Diss. Institut für Pflanzenbau der Rheinischen Friedrich-Wilhelms-Universität Bonn. $161 \mathrm{p}$.

Kaul, H.-P., Scheer-Triebel, M. \& Heyland, K.-U. 1994. Selection criteria for short-fibre flax. Plant Breeding 113: $130-136$.

Kromer, K.-H., Gottschalk, H. \& Beckmann, A. 1995. Technisch nutzbare Leinfaser. Landtechnik 6 : 340-341.

Mäkinen, M. 1998. Öljypellavan kuitututkimukset. In: Luostarinen, M. et al. (eds.). Öljypellavan kuidun hyödyntäminen [Utilization for linseed flax fibre] (Abstract in English). Maatalouden tutkimuskeskuksen julkaisuja. Sarja A 45. Maatalouden tutkimuskeskus, Jokioinen. p. 18-26.

Meijer, W.J.M., Vertregt, N., Rutgers, B. \& Waart, M. van de 1995. The pectin content as a measure of the retting and rettability of flax. Industrial Crops and Products 4: 273-284. 
Vol. 9 (2000): 79-87.

Neter, J., Kutner, M.H., Nachtsheim, C.J. \& Wasserman, W. 1996. Applied Linear Statistical Models. 4th ed. Irwin, Chicago, IL. 1408 p.

Reijonen, A. 1998. Johtopäätökset öljypellavan kuidun soveltuvuudesta nykyaikaiseen teollisuustuotantoon. In: Luostarinen, M. et al. (eds.). Öljypellavan kuidun hyödyntäminen [Utilization for linseed flax fibre] (Abstract in English). Maatalouden tutkimuskeskuksen julkaisuja. Sarja A 45. Maatalouden tutkimuskeskus, Jokioinen. p. 27-49.

Sankari, H.S. 2000. Linseed (Linum usitatissimum L.) cultivars and breeding lines as stem biomass producers. Manuscript accepted for publication in
Journal of Agronomy \& Crop Science.

SAS Institute Inc. 1991. SAS Language and Procedures: Usage 2, Version 6. 1st ed. SAS Institute Inc., Cary, NC. 649 p.

- 1992. SAS Technical Report P-229. SAS/STAT Software: Changes and Enhancements, Release 6.07. SAS Insitute Inc., Cary, NC. 620 p.

Turner, J. 1987. Linseed Law. A handbook for growers and advisers. BASF U.K. Ltd, Suffolk. 356 p.

Werf H.M.G. van der, Harsveld van der Veen, J.E., Bouma, A.T.M. \& Ten Cate, M. 1994. Quality of hemp (Cannabis sativa L.) stems as raw material for paper. Industrial Crops and Products 2: 219-227.

\title{
SELOSTUS
}

\section{Öljypellavagenotyyppien niinikuitupitoisuus, kuitusato ja kuidun laatu}

\author{
Hannele S. Sankari \\ Maatalouden tutkimuskeskus
}

Öljypellavaa (Linum usitatissimum L.) viljellään siementuotantoa varten eikä se tuota kilpailukykyistä kuitusatoa kuitupellavaan verrattuna. Öljypellavan viljelyn sivutuotteena syntyviä varsia voitaisiin kuitenkin käyttää erilaisissa non-woven -tuotteissa.

Suomalaisen Helmi-öljypellavan varsisatoa, varren niinikuitupitoisuutta, varren pituutta ja läpimittaa sekä niinikuitusatoa verrattiin kymmenen muun öljypellavagenotyypin ja yhden kuitupellavan suhteen tarkoituksena löytää öljypellavagenotyyppejä, jotka sopisivat yhtä aikaa sekä siemen- että varsituotantoon Suomessa. Lisäksi määritettiin kuidun murtolujuus ja murtovenymä. Kokeet tehtiin vuosina 19961997 Maatalouden tutkimuskeskuksessa (MTT) Joki- oisilla. Kaikkien pellavien keskimääräinen varren niinikuitupitoisuus oli 16,9\%. Jalostuslinja Bor 18:n kuitupitoisuus oli merkitsevästi Helmin kuitupitoisuutta suurempi. Kaikkien pellavien keskimääräinen niinikuitusato oli $301 \mathrm{~kg}$ kuiva-ainetta hehtaarilta. Helmiin verrattuna jalostuslinjat Bor 15 ja Bor 18 sekä Flanders- ja Gold Merchant -lajikkeet tuottivat merkitsevästi suuremman kuitusadon. Genotyypistä riippuen kuidun murtolujuuden mediaaniarvot vaihtelivat välillä 40 ja $67 \mathrm{cN} /$ tex ja kuidun murtovenymän mediaaniarvot välillä 3,5 ja $6,8 \%$. Suomalaista öljypellavan jalostuslinjaa Bor 18 suositellaan viljeltäväksi, kun sekä öljypellavan siemen- että varsisato aiotaan hyödyntää. 